\title{
Use of fleshings-derived collagen in chrome tanning process
}

\author{
Monica Puccini ${ }^{1, a}$ and Domenico Castiello ${ }^{2, b}$ \\ ${ }^{1}$ Department of Civil and Industrial Engineering, University of Pisa, Largo Lucio Lazzarino 1, 56122 \\ Pisa, Italy \\ ${ }^{2}$ Po.Te.Co. Scrl - Polo Tecnologico Conciario, Via Walter Tobagi, 30, 56022 Castelfranco di Sotto \\ (Pisa), Italy \\ amonica.puccini@unipi.it, bd.castiello@polotecnologico.com
}

Keywords: tanning process, collagen hydrolizate, chromium tannage

\begin{abstract}
The manufacturing process to transform hides into leather requires a series of chemical and mechanical operations. Fleshings represent one of the most important byproduct of the leather compartment. They are mainly constituted of raw collagen and through an alkaline hydrolysis a collagenous solution is obtained. In this work, an experimental activity research was performed for assessing the feasibility of the reuse of the collagen hydrolizate solution in the tanning phase. The hydrolizate has been used in combination with chromium salts to obtain bovine upper leather up to a dosage of $20 \%$ of solution ( $68 \%$ dry protein matter content) on the fleshed hide weight. Following a laboratory scale screening of the optimal operating conditions, crust leathers have been obtained on pilot scale. The final leather shows similar properties to those of the traditionally tanned leather in terms of technical and mechanical properties. Furthermore, a dry tannage is feasible, thus avoiding the production of effluents, and it is possible to adopt a retannage/dyeing/fatliquoring characterized by a lower consumption of chemicals in comparison with the standard procedure. The results obtained indicate the use of the collagen hydrolizate in the tanning phase as an interesting route for valorisation of fleshings.
\end{abstract}

\section{Introduction}

Tanning essentially is the process of converting raw hides and skins into imputrescible substance. The leather making process has number of steps and generates significant quantities of liquid and solid wastes. Many cleaner approaches aimed at reduction of wastes proved to be environmentally beneficial [1]. The most common way to manage solid wastes is by disposing of them on identified land sites. Solid wastes generated in leather industries include skin trimmings, keratin wastes, fleshings, chrome shaving wastes and buffing wastes [2]. Protein is the main component of most of these wastes. If these protein and other unspent chemicals, are not utilized or treated properly they could pose serious environmental problems threatening the sustainability of leather making. Research interest has thus focused on the development of processes for recycling these wastes by finding suitable industrial uses either in the tanning [3-6] or in other industrial sectors [7-10].

Fleshings represent one of the most important wastes of the leather industry. The fleshing operation is carried out to remove flesh and natural fats from the skins, since the presence of fats could accelerate skin degradation. Besides, the fat layer makes difficult the penetration of chemicals in subsequent operations. A measure of its environmental impact is given by the wastes from fleshing of the industrial tannery district of Santa Croce sull'Arno (Italy), whose production is close to 80,000 tons/year. In Santa Croce, the fleshing of the whole district is collected and processed in a centralized plant where, through an alkaline hydrolysis, a raw collagen hydrolizate solution is obtained. The high content of salts of the raw collagen hydrolizate, whose separation is rather expensive, represents an obstacle to reutilization and recovery. 
In this study, the results obtained by recycling, in the tanning phase, the collagen hydrolizate solution, as it is obtained through the alkaline treatment without any further processing or modification, were reported. The tannage has been developed for the production of bovine upper leather. Following the laboratory phase, in which the optimal dosages and procedures have been set up, the tanning procedure has been validated on a semi-industrial scale.

\section{Experimental procedures}

The raw collagen hydrolizate solution was supplied by S.G.S. S.p.A. of Santa Croce sull'Arno (Italy), a centralized plant that treats the wastes from fleshing of all the Tuscany leather district. The hydrolizate solution is obtained through alkaline hydrolysis, degreasing, and concentration. Basic chromium (III) sulfate $\left(26 \% \mathrm{Cr}_{2} \mathrm{O}_{3}, 33 \%\right.$ basicity) was used as tanning agents.

The tanning runs on laboratory scale were performed in cylindrical stainless steel drums $(35 \mathrm{~cm}$ diameter, $20 \mathrm{~cm}$ length), rotating in a controlled temperature water bath (30 rpm rotation speed). In each run, the drum was loaded with one hide sample (average weight $300 \mathrm{~g}$ ), cut from calf hides (8$12 \mathrm{~kg}$ ) after the pickling stage ( $\mathrm{pH} 2.6)$.

The semi-industrial scale tanning runs were conducted in a stainless steel drum (1.2 $\mathrm{m}$ diameter, 0.8 $\mathrm{m}$ length) by using the same pickled hides. The hides were divided into two sides: one side was conventionally tanned with chromium, the other side was tanned according to the innovative recipes. After pressing, splitting and shaving, the two halves were reunited to follow a retannage/dyeing/fatliquoring cycle to obtain crust leathers currently used by the tannery to produce upper leathers.

The crust leathers were evaluated by their main physical and technical properties. Physical testing were conducted according to Italian standards (UNI 10594) for upper leather. The tearing load was determined according to the UNI EN ISO 3377:2 method by using a dinamometer Pegasil Model Marte. The data reported are the mean of eight determinations. The grain distension was determined according to the UNI EN ISO 3379 method by using a lastometer Pegasil Model EL-51E. The data reported are the mean of four determinations. The shrinkage temperature was determined according to the UNI-ISO 3380 method by using a Giuliani IG/TG/THEISS equipment. The data reported are the mean of two determinations. Scanning electron microscopy (SEM) was conducted by using a JEOL 5600 LV electron scanning microscope.

\section{Results and discussion}

The composition of the collagen hydrolizate solution used in this study is reported in Table 1 . The salts content appears quite elevated and it is due mainly to the presence of $\mathrm{NaCl}$, used in the conservation of the hides. Besides, the protein phase is characterized by a quite low molecular weight and by the presence of a significant percentage of free amino acids. This composition is due to the high degree of hydrolysis of the polypeptides induced by the strong alkaline treatment.

Use of the collagen hydrolizate in the chromium tannage: laboratory scale runs. A dry chromium tannage was applied. The tanning runs were performed by varying either the sequence of addiction of chrome and collagen hydrolizate (HYD), either their dosages, according to the scheme and recipes reported in Table 2. Run 1 is a blank tanning run with chrome. Table 3 reports the shrinkage temperature of the tanned hides obtained by using chromium and hydrolizate and following the different sequences and dosages. The addiction of the hydrolizate does not affect significantly the hydrothermal stability of the skin at the two dosages experimented, and neither the sequence of addiction. In order to select the best sequence, the samples of tanned hide were fatliquored to assess preliminary the technical properties. By this assessment, the chromehydrolizate sequence was selected.

Use of the collagen hydrolizate in the chromium tannage: pilot scale runs. The pilot scale runs were performed by adopting the best sequence chrome-hydrolizate and by using the dosages of $8 \%$ chrome and 10 or $20 \%$ hydrolizate, according to the procedures described in Table 2 . Also in this case, a dry tannage was adopted. The final shrinkage temperature of the tanned leather results $94^{\circ} \mathrm{C}$ 
at $10 \%$ of hydrolizate dosage and $98^{\circ} \mathrm{C}$ at $20 \%$, against a shrinkage temperature close to $100^{\circ} \mathrm{C}$ obtained for the leather conventionally tanned with chrome. This result confirms the observations made in the laboratory scale runs. Figure 1 reports the SEM images of the section of leather after tanning. The leather tanned by using also the hydrolizate reveals a good compactness and orientation of the collagen fibrils, comparable to those displayed by the chromium-only tanned leather.

Following these promising results, two different retannage/dyeing/fatliquoring were investigated. The hides tanned by using $10 \%$ hydrolizate was processed according to a standard retannage/dyeing/fatliquoring cycle (mixed chrome vegetable retannage), whilst the hides tanned with $20 \%$ hydrolizate was processed according to a lighter retannage/dyeing/fatliquoring cycle (vegetable retannage) characterized by a lower consumption of chemicals.

\begin{tabular}{|c|c|c|c|}
\hline Dry matter $(w t \%)$ & 68 & & \\
\hline Ashes $\left(800^{\circ} \mathrm{C}\right)$ & 14 & & \\
\hline Nitric nitrogen (wt $\%)$ & 0.4 & & \\
\hline Organic nitrogen $(\mathrm{wt} \%)$ & 6.5 & & \\
\hline Organic carbon (wt $\%)$ & 23.5 & & \\
\hline Free amino acids $(\mathrm{wt} \%)$ & 7.9 & & \\
\hline \multirow[t]{2}{*}{ Total amino acids (wt\%) } & 54 & & \\
\hline & Amino acids speciation $(\mathrm{wt} \%)$ : & Aspartic acid & 1.7 \\
\hline $\mathrm{S}\left(\right.$ as $\left.\mathrm{SO}_{2}, \mathrm{mg} / \mathrm{kg}\right)$ & 385 & Glutamic acid & 3.9 \\
\hline $\mathrm{P}\left(\right.$ as $\left.\mathrm{P}_{2} \mathrm{O}_{5}, \mathrm{mg} / \mathrm{kg}\right)$ & 33.6 & Glycine & 16.4 \\
\hline $\mathrm{K}(\mathrm{mg} / \mathrm{kg})$ & 990 & Hydroxyproline & 3.1 \\
\hline $\mathrm{Ca}($ as $\mathrm{CaO}, \mathrm{mg} / \mathrm{kg})$ & 853 & Leucine & 2.4 \\
\hline $\mathrm{Na}(\mathrm{wt} \%)$ & 9.9 & Lysine & 3.2 \\
\hline $\mathrm{Cl}(\mathrm{wt} \%)$ & 6.1 & Methionine & 4.6 \\
\hline Density $\left(\mathrm{g} / \mathrm{cm}^{3}\right)$ & $1.25-1.28$ & Proline & 7.3 \\
\hline $\mathrm{pH}$ & $7.0-7.5$ & Other & 11.4 \\
\hline Mean molecular weight (kDa) & 1.84 & & \\
\hline Cinematic viscosity $\left(25^{\circ} \mathrm{C}, \mathrm{cSt}\right)$ & 360 & & \\
\hline Dynamic viscosity $\left(25^{\circ} \mathrm{C}, \mathrm{Pa} \cdot \mathrm{s}\right)$ & 0.17 & & \\
\hline
\end{tabular}

Table 1. Composition and chemical-physical properties of the collagen hydrolizate solution.

\begin{tabular}{|c|l|lrl|}
\hline Run & Sequence and Dosages & Recipe & & \\
\hline 1 & Chrome ${ }^{\mathrm{a}} 8 \%$ & Crome & $8 \%$ & $4 \mathrm{hr}$ \\
& & MgO & $0.25 \%$ & overnight \\
\hline 2 & Crome $8 \% \rightarrow$ HYD 10\% & Crome & $8 \%$ & $4 \mathrm{hr}$ \\
& & HYD & $10 \%$ & $4 \mathrm{hr}$ \\
& & MgO & $0.25 \%$ & overnight \\
\hline 3 & HYD 10\% $\rightarrow$ Chrome 8\% & HYD & $10 \%$ & $4 \mathrm{hr}$ \\
& & Crome & $8 \%$ & $4 \mathrm{hr}$ \\
& & MgO & $0.25 \%$ & overnight \\
\hline 4 & Chrome 8\% + HYD 20\% & Crome & $8 \%$ & $4 \mathrm{hr}$ \\
& & HYD & $10 \%$ & $4 \mathrm{hr}$ \\
\hline
\end{tabular}

${ }^{\mathrm{a}}$ Chromium (III) sulfate (33\% basicity)

Table 2. Scheme and recipes of the laboratory scale tanning runs with chrome and collagen hydrolizate solution (HYD). The dosages are reported as $w t \%$ on the fleshed hide weight. 


\begin{tabular}{|l|c|}
\cline { 2 - 2 } \multicolumn{1}{c|}{} & Shrinkage temperature, ${ }^{\circ} \mathrm{C}$ \\
\hline Chrome $8 \%$ & 100 \\
Crome $8 \% \rightarrow$ HYD $10 \%$ & 97 \\
HYD $10 \% \rightarrow$ Chrome $8 \%$ & 97 \\
Chrome $8 \%+$ HYD $20 \%$ & 98 \\
\hline
\end{tabular}

Table 3. Shrinkage temperature of the chrome-hydrolizate tanned leather at laboratory scale.

Table 3 reports the results of the mechanical tests of the crust leathers obtained. The results of the assessment of the technical properties of the novel crust leathers, in comparison with the conventionally chrome tanned leather, are reported in Table 4. A conventional scale of grades ranging from 1 (worst performance) to 5 (best performance) has been used. The crust leathers comply very well with the standards required for high quality bovine upper leather. It may be observed that the crust leathers obtained by the addiction of the hydrolizate shows better roundness, fullness, hand and, specifically, a better quality of the dyeing that results more intense, homogeneous and bright. It is interesting to note the good results obtained by adopting a $20 \%$ dosage of hydrolizate and, contemporary, a retannage/dyeing/fatliquoring at lower chemical consumption.
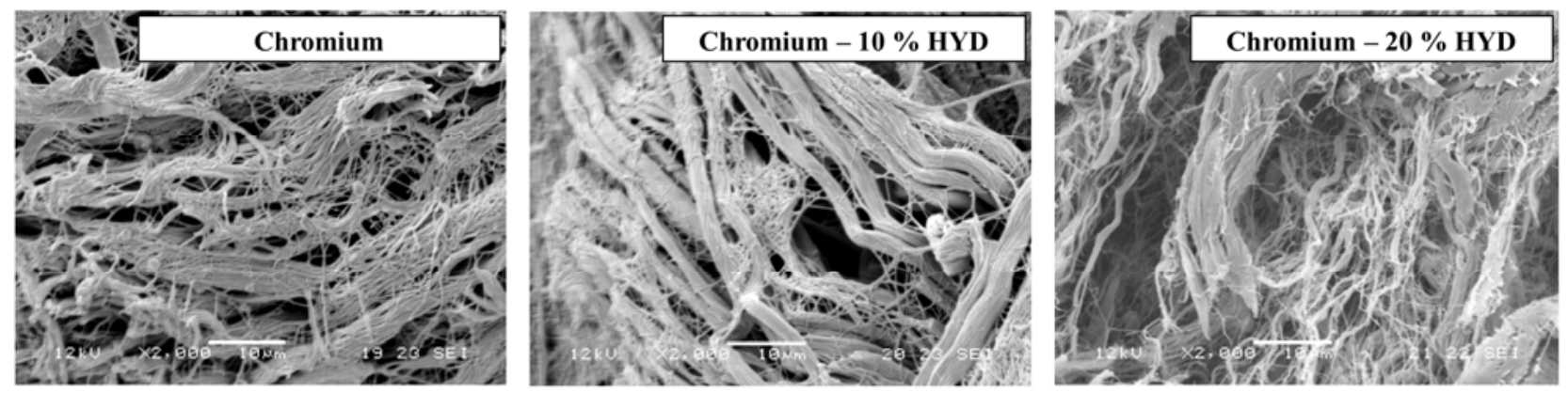

Fig. 1. SEM pictures of the section of the tanned leather with chromium $8 \%$, chromium $8 \%$ hydrolizate $10 \%$, cromium $8 \%$ - hydrolizate $20 \%$ (dosages on the fleshed hide weight).

\begin{tabular}{|l|c|c|c|c|c|}
\cline { 2 - 5 } \multicolumn{1}{l|}{} & Blanck & HYD 10\% & Blanck & HYD 20\% & $\begin{array}{c}\text { UNI 10594 } \\
\text { guidelines }\end{array}$ \\
\hline $\begin{array}{l}\text { Tearing load (N) } \\
\text { ISO 3377 method }\end{array}$ & 175.8 & 148.7 & 90.6 & 87.6 & $30 \div 80^{\mathrm{a}}$ \\
\hline $\begin{array}{l}\text { Grain distension (mm) } \\
\text { UNI ISO 3379 method }\end{array}$ & 9.2 & 8.6 & 10.2 & 9.3 & $\geq 7$ \\
\hline
\end{tabular}

${ }^{\text {a }}$ depending on use

Table 3. Physical tests results of the chrome crust leather obtained on pilot scale. 


\begin{tabular}{|l|c|c|c|c|}
\cline { 2 - 5 } \multicolumn{1}{c|}{} & \multicolumn{4}{c|}{ Crust leather } \\
\hline Technical properties & Blanck & HYD $10 \%$ & Blanck & HYD 20\% \\
\hline Color homogeneity & 4 & 4 & 3 & 4 \\
\hline Color yield & 3 & 5 & 2 & 5 \\
\hline Roundness & 4 & 5 & 3 & 4 \\
\hline Fullness & 4 & $4 / 5$ & 3 & 4 \\
\hline Hand & 4 & 5 & 4 & $4 / 5$ \\
\hline Grain quality & 5 & 5 & 3 & 4 \\
\hline Softness & $4 / 5$ & 4 & 4 & $3 / 4$ \\
\hline
\end{tabular}

Table 4. Technical properties of the chrome crust leather obtained on pilot scale.

\section{Conclusions}

The present study assess the feasibility of the use, in the tanning phase, of the collagen hydrolizate obtained by alkaline hydrolysis of the fleshings, one of the most important byproduct of the leather compartment. The hydrolizate has been used in combination with chromium salts to obtain bovine upper leather up to a dosage of $20 \%$ of solution $(68 \%$ dry content) on the fleshed hide weight. Following a laboratory scale screening of the optimal operating conditions, crust leathers have been obtained on pilot scale. The hydrolizate solution may be used as it is obtained by the industrial alkaline hydrolysis process currently adopted in the Santa Croce sull'Arno tanning district. The final leathers show similar properties in terms of hydrothermal stability, grain distension and tearing load respect to conventionally tanned hides. The salts content of the solution is not damaging of the physical and technical properties of the final leather, or rather the introduction of the hydrolizate in the hide structure produces better technical qualities, particularly in terms of better quality of the dyeing that results more intense, homogeneous and bright. Besides, a dry chrome tannage is feasible, thus avoiding the production of effluents and it is possible to adopt a retannage/dyeing/fatliquoring characterized by a lower consumption of chemicals in comparison with the standard procedure. The results obtained indicate that the use of the collagen hydrolizate in the tanning phase as an interesting route for recovering the fleshings.

\section{References}

[1] M. Puccini, M. Seggiani, D. Castiello, S. Vitolo: Chem. Eng. Trans. Vol. 36 (2014), p. 193

[2] W. Schramm: J. Cleaner. Prod. Vol. 5(4) (1997), p. 291

[3] M. Puccini and D. Castiello: Appl. Mech. Mater. Vol. 597 (2014), p. 144

[4] M. Gutterres M. And I.V. Da Silva IV: J. Am. Leather Chem. Ass. Vol. 105 (2010), p. 195-202

[5] W. Chen, P.H. Cooke, G. Di Malo, M.M. Taylor and E.M. Brown: J. Am. Leather Chem. Ass. Vol. 96(7) (2001), p 262

[6] C.S. Cantera, M. Giuste and A. Sofia: J. Soc. Leather Technol. Chem. Vol. 81(5) (1997), p. 183

[7] M. Puccini, D. Castiello, M. Seggiani, and S. Vitolo, Adv. Mater. Res. Vol. 893 (2014), p 235

[8] M. Puccini, M. Seggiani, D. Castiello, G. Calvanese and S. Vitolo: App. Mech. Mater. Vol. 467 (2014), p. 41

[9] D. Castiello, E. Chiellini, P. Cinelli, S. D’Antone, M. Puccini, M. Salvadori and M. Seggiani: J. Appl. Polym. Sci. 114(6) (2009), p. 3827

[10]M. Puccini, M. Seggiani, D. Castiello and S. Vitolo: Adv. Mater. Res. 849 (2014), p. 397 